Georgetown University Law Center

Scholarship @ GEORGETOWN LAW

1992

\title{
Environment and Trade as Partners in Sustainable Development: A Commentary
}

Edith Brown Weiss

Georgetown University Law Center, weiss@law.georgetown.edu

This paper can be downloaded free of charge from:

https://scholarship.law.georgetown.edu/facpub/1626

86 Am. J. Int'I L. 728 (1992)

This open-access article is brought to you by the Georgetown Law Library. Posted with permission of the author. Follow this and additional works at: https://scholarship.law.georgetown.edu/facpub

Part of the Environmental Law Commons, International Law Commons, and the International Trade Law $\underline{\text { Commons }}$ 


\section{Environment and Trade as Partners in Sustainable DEVELOPMENT: A COMMENTARY}

Trade is not an end in itself; rather, it is a means to an end. The end is environmentally sustainable economic development. ${ }^{1}$ So viewed, there are legitimate constraints on trading patterns and practices that are necessary to ensure that the "instrument of trade" leads to environmentally sustainable development. Measures needed to protect the environment cannot be forsworn simply because they may adversely affect free trading relationships.

When we link environmental protection and free trade in the framework of environmentally sustainable development, we necessarily adopt a long-term perspective. Sustainable development is inherently intergenerational. This, too, imposes limits on the extent to which we are able to maximize consumption today without concern for the legacy we pass to future generations. ${ }^{2}$

Until recently, most discussion of trade and environment issues focused on facilitating freer trading relationships, and hence on fitting environmental issues into the framework of trade law. In his article, Thomas Schoenbaum uses the traditional approach of identifying environmental issues that have raised questions of consistency with the GATT, and then applying and extending the GATT to the environmental issues. ${ }^{3}$ While the approach is carefully set forth, the resolution of environment and trade issues requires a framework in which environmental concerns are given billing comparable to those of trade, and both are viewed in the integrating context of environmentally sustainable development and economic growth.

The asymmetry of development between environmental and trade laws is a historical accident. After World War II, countries were concerned about avoiding a depression like the one that had followed World War I. Thus, they wanted to be sure to put in place a regime that would promote free trade and squash protectionism. They sought to establish an International Trade Organization, but in the end had to settle for the General Agreement on Tariffs and Trade, which eventually became the venerable framework for trading relationships. ${ }^{4}$

In the immediate postwar period, countries were not concerned with the environment, because they had not yet recognized their capacity to degrade it irreversibly on a large scale, with one notable exception: the waging of nuclear warfare. Rachel Carson's famous book, The Silent Spring, which fostered environmental

\footnotetext{
${ }^{1}$ Arthur Dunkel, the Director-General of GATT, explicitly acknowledged this dynamic in his plenary presentation to the United Nations Conference on Environment and Development, Rio de Janeiro, June 11, 1992. See also World Commission on Environment And Development, Our COMMON FUTURE (1987). The Brundtland Commission defined sustainable development "as a process of change in which the use of resources, the direction of investments, the orientation of technological developments, and institutional change all enhance the potential to meet human needs both today and tomorrow." Id. at 46.

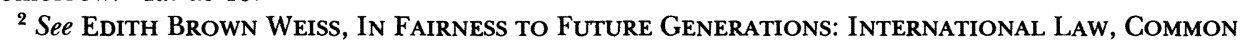
PATRIMONY, AND INTERgENERATIONAL EQUITY (1989). Moreover, since free trade is regarded as enhancing competitiveness, it is important to note that competitiveness has an intergenerational dimension, so that environmentally unsustainable trade practices today may affect competitiveness tomorrow.

${ }^{3}$ Thomas J. Schoenbaum, Free International Trade and Protection of the Environment: Irreconcilable Conflict?, supra p. 700.

${ }^{4}$ General Agreement on Tariffs and Trade, Oct. 30, 1947, TIAS No. 1700, 55 UNTS 188 [hereinafter GATT]. For an introduction to the history of these efforts, see JOHN H. JACKSON \& WILLIAM J. Davey, Legal Problems of International Economic Relations 293-301 (2d ed. 1986), and material cited therein.
} 
consciousness, was not published until $1962 .{ }^{5}$ The first major piece of U.S. national environmental legislation, the National Environmental Policy Act, ${ }^{6}$ was enacted only in 1969. In 1972 countries held the first United Nations conference concerned with environmental issues, which led directly to the formation of the United Nations Environment Programme. ${ }^{7}$ Today, only two decades later, there are almost nine hundred international legal instruments that either are fully devoted to environmental issues or have one or more significant provisions directed to environmental protection. ${ }^{8}$

Even so, there is no general international agreement on environmental and natural resource protection, as there is on tariffs and trade. ${ }^{9}$ The international environmental framework consists of many separate legal instruments, some with overlapping provisions and each with a differing set of countries as parties. It is perhaps not surprising that the environment/trade debate is focused on how environmental issues can be squared with the one internationally accepted legal framework that does exist-the General Agreement on Tariffs and Trade, the codes from the Multilateral Trade Negotiations and related instruments. ${ }^{10}$ What is needed is a framework for environmentally sustainable development, in which both international environmental principles and GATT principles can be equal and integral parts.

If we were to have such a framework, the way we now view trade and environment issues would change. Several examples illustrate the difference.

First, the effect of trading practices on protection of the environment would be given much greater attention. The relationship between more open trade and environmental protection is contentious. Protectionist practices might well be viewed as generally promoting environmental degradation because they provide no incentive to use resources efficiently. Free trade might justifiably be viewed as promoting environmental protection, because countries will generate more wealth with which to protect the environment.

However, some argue that free trade leads to a Gresham's law, a competitiveness toward less stringent environmental regulation and protection, and that industries will migrate to areas with lower environmental standards. But there is as yet little evidence that investments have migrated to countries on the basis of lower environmental standards. ${ }^{11}$

\footnotetext{
${ }^{5}$ Rachel Carson, The Silent Spring (1962).

${ }^{6}$ Pub. L. No. 91-190, 83 Stat. 852 (1969), 42 U.S.C. $§ \S 4321-4347$ (1988).

${ }^{7}$ Report of THE UNited Nations Conference on the Human ENVironment, UN Doc. A/ CONF.48/14, reprinted in 11 ILM 1416 (1972).

${ }^{8}$ For a comprehensive list, see Edith Brown Weiss, Daniel B. Magraw \& Paul C. Szasz, InterNATIONAL ENVIRONMENTAL LAW: BASIC INSTRUMENTS AND REFERENCES (1992).

${ }^{9}$ There have been several preliminary efforts to develop such an agreement. See EXPERTS GrouP ON ENVIRONMENTAL LAW OF THE WORLd COMMISSION ON ENVIRONMENT AND DEVELOPMENT, ENVIronmental Protection and Sustainable Development: Principles and Recommendations (1986); Draft Covenant on Environmental Conservation and Sustainable Use of Natural Resources, 21 ENVT'L POL'Y \& L. 221 (1991); and even the Rio Declaration on Environment and Development (June 14, 1992), UN Doc. A/CONF.151/5/Rev.1, reprinted in 31 ILM 874 (1992), which sets forth general principles.

${ }^{10}$ GATT, supra note 4 (entered into force Jan. 1, 1948); GATT, BASIC INSTRUMENTS AND SELECTED DOCUMENTs, 26th Supp. 8 (1980). For an overview of the agreements resulting from the multilateral trade negotiations, see John H. Jackson, The Birth of the GATT-MTN System: A Constitutional Appraisal, 12 LAW \& POL'Y INT'L BuS. 21 (1980).

${ }^{11}$ See Jeffrey Leonard, Pollution and the Struggle for the World Product (1988). But see U.S. General ACcounting Office, U.S.-Mexico Trade: Some U.S. WoOd Furniture Firms ReloCATED From LoS ANGeles AREa to MeXico (No. GAO/NSIAD-91-191, 1991), which reports that $1-3 \%$ of wood furniture manufacturers in the Los Angeles area migrated to Mexico between 1988
} 
The relationship between the environment and trade in different stages of economic development is also contentious. Some liken that relationship to an inverted U-shaped curve; countries that are just beginning the process of economic development cause serious environmental degradation up to the point at which they acquire sufficient wealth to generate both a demand to protect the environment and the resources with which to do it. At this point, free trade practices promote environmental protection. ${ }^{12}$

Focusing on the environmental effects of trade practices raises the question of how to identify and assess these effects in a way that can be considered in the decision-making process. Environmental reviews for major trade measures are one possibility. ${ }^{13}$

Second, from the environmental perspective, the distinction made in the GATT panel's Tuna Dolphin report between product and process takes on a different hue when environmentally sustainable development is taken into account. ${ }^{14}$ The panel affirmed that countries could constrain the import of products that were harmful to the domestic environment of the importing country if the products were accorded national treatment on a nondiscriminatory basis, but could not ban imports of products made by processes that were harmful to the environment or to living resources (in this case, the fishing practices for yellowfin tuna, which were harmful to dolphins).

Yet, from the viewpoint of environmentally sustainable development, the process by which products are made is as important as the product. Maintaining the environmental services of our planet is essential to its robustness and hence to sustainable development. Without the ability to ban products produced by environmentally unsustainable practices, countries will be lacking an essential measure for achieving environmentally sustainable development, since the measure is precisely tailored to deterring the unwanted practice. This does not mean that all such bans should a fortiori be acceptable, but rather that the starting point for judging such measures should be that they may be necessary to achieve environmentally sustainable development. ${ }^{15}$

To be sure, the traditional concern of all countries has been their sovereign right to exploit natural resources, ${ }^{16}$ which includes the manner of exploiting these resources, whether sustainable or unsustainable. But this right has been increasingly tempered, as evidenced by the Stockholm Declaration on the Human Envi-

and 1990, in part because of less-stringent environmental requirements. Increasingly, multinational firms are adopting common environmental standards for their plants for reasons of efficiency, which removes any migration incentive to take advantage of lower environmental standards.

${ }^{12}$ For analysis of this curve and other relevant factors in the environment/trade nexus, see Patrick Low \& Raed Safadi, Trade Policy and Pollution (paper delivered at World Bank Symposium on International Trade and Environment, November 1991).

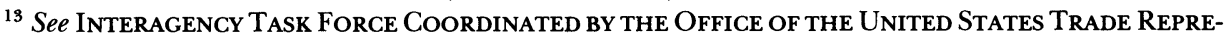
SENTATIVE, REVIEW OF U.S.-MEXICO ENVIRONMENTAL ISSUES (1991) (prepared in connection with the proposed North American Free Trade Agreement).

${ }^{14}$ United States-Restrictions on Imports of Tuna, GATT No. DS21/R (Sept. 3, 1991), reprinted in 30 ILM 1594 (1991).

${ }^{15}$ The trading regime may also need to address process questions in the future since, arguably, competitiveness in the 21 st century will rest more on the process of production than on the product. See lester Thurow, Head to Head: The Coming Economic Battle among Japan, Europe, And AMERICA (1992).

${ }^{16}$ See Permanent Sovereignty over Natural Resources, GA Res. 3171, UN GAOR, 28th Sess., Supp. No. 30, at 52, UN Doc. A/9030 (1973), which refers to six earlier General Assembly resolutions concerned with permanent sovereignty over natural resources. 
ronment of 1972 (Principle 21) ${ }^{17}$ and the documents for the 1992 United Nations Conference on Environment and Development, in particular the Rio Declaration on Environment and Development ${ }^{18}$ and the lengthy Agenda 21, which covers most aspects of environment and development. It is an anachronism that at a time when people are focusing on changing development practices to make them sustainable, the trading community is forbidding the use of trade measures to assist in this process.

If we accept that environmental conservation and free trade are both means for reaching a common end of environmentally sustainable development (as opposed to the present approach of considering environment and trade problems only in the context of the existing trade regime), we must address an important issue that is sometimes neglected: appropriate dispute resolution mechanisms. The framework for resolving disputes between the two bodies of law cannot be assumed to be the present dispute resolution mechanism of the GATT. Much attention needs to be given to the appropriate forum(s) and to the procedures for resolution of environment and trade disputes. Both kinds of expertise-environmental and trade-should be included to ensure resolution that fully considers the concerns of both sectors. ${ }^{19}$

Schoenbaum identifies four categories of environment and trade issues, all of which he calls trade restrictions in the name of environmental quality: regulation of imports and exports to protect the domestic environment; ${ }^{20}$ trade restrictions to enforce environmental standards in international agreements; trade restrictions in response to perceived inadequate environmental protection controls in other countries; and controls on the export of hazardous products, technologies and wastes.

In his article, Schoenbaum does not distinguish what has become an important environment and trade issue: trade restrictions to protect areas outside the jurisdiction of countries in the absence of formal international agreement. These could arise in the context of threats to marine living resources, new threats to the ozone layer not covered by the Montreal Protocol, or pollution problems in outer space. Schoenbaum regards any possible unilateral use of trade instruments to respond to the practices of other countries, which implicitly includes measures to protect the environment of areas outside national jurisdiction, as "unbridled unilateralism" that "would reduce international trade to a power-based regime that

\footnotetext{
${ }^{17}$ For a thorough analysis of the history and intent of the Stockholm Declaration, infra note 20, see Louis B. Sohn, The Stockholm Declaration on the Human Environment, 14 HARV. J. INT'L L. 423 (1973).

${ }^{18}$ Note 9 supra.

${ }^{19}$ The 1992 North American Free Trade Agreement is innovative in that it provides for a dispute settlement panel to request a written report from an independent scientific review board on factual issues concerning the environment and puts the burden of proof on the party challenging the environmental measure to show that it is inconsistent with the agreement. U.S. Environmental Protection Agency, Statement on the North American Free Trade Agreement and accompanying summary of provisions of agreement (Aug. 12, 1992).

${ }^{20}$ As Schoenbaum notes, it is well-accepted practice that countries under the GATT may restrict imports to protect aspects of their domestic environment, provided that the restrictions are nondiscriminatory and the principle of national treatment is applied. For detailed treatment of this issue, see Steve Charnovitz, Exploring the Environmental Exceptions in GATT Article XX, 25 J. WORLD TRADE L. 37 (1991). However, even if products are imported that do not fall within the GATT Article XX exceptions, there would still be a possibility of individual actions in the importing country against environmentally deleterious imports. See Anthony D'Amato \& Kirsten Engel, State Responsibility for the Exportation of Nuclear Power Technology, 74 VA. L. REv. 1011, 1056-66 (1988).
} 
would have no stability or rationality."21 But surely there may be instances where countries are at the forefront of identifying risks to areas of common concern and should not be forced as a principle of international law to continue to contribute to such environmental degradation. Indeed, Principle 21 of the Stockholm Declaration provides that countries have an obligation to ensure that activities within their jurisdiction and control do not cause harm to areas outside their jurisdiction and control, which arguably includes globally common areas. ${ }^{22}$ Do we really want in all instances to say that countries are precluded from using any trade restrictions to enforce violations of this provision (which many view as customary international law), or violations of legal instruments that may not be formal agreements but incorporate this or similar obligations? In integrating the interests of environment and trade, further attention needs to be given to this set of issues, the reference in the Rio Declaration notwithstanding. ${ }^{23}$

A related concern arises from unilateral restraints on imports designed to protect those aspects of the environment within other countries that may have international or regional importance, or resources impressed with common patrimony. The latter could perhaps extend to world heritages or to the conservation of forests rich in biological diversity.

Since unilateral measures in support of environmentally sustainable development could encompass many activities traditionally viewed as solely within national jurisdiction, the implications of the unilateral use of trade measures are indeed far-reaching. For one state to try to affect the environmental standards that another uses by keeping out its products raises concerns about eco-imperialism. However, if states have reached international agreement on these standards and procedures, unilateral measures would be seen as implementing international norms. Similarly, if some legal instruments may be less than binding, such as the FAO Code of Conduct on the Distribution and Use of Pesticides ${ }^{24}$ and the London Guidelines for the Exchange of Information on Chemicals in International Trade,${ }^{25}$ they represent a sufficient international consensus to enable the adoption of national measures to implement them. ${ }^{26}$

The more difficult questions arise in the absence of a formal international legal consensus. Under what circumstances can one country bar products from another on the basis of concern that the product or process of production is causing harm

${ }^{21}$ Schoenbaum, supra note 3 , at 723.

${ }^{22}$ Declaration on the Human Environment (June 16, 1972), in REPORT OF THE UNITED NATIONS Conference on THE Human Environment, supra note 7, at 3; see generally Jeffrey L. Dunoff, Reconciling International Trade with Preservation of the Global Commons: Can We Prosper and Protect? (unpublished manuscript 1992, on file with the author).

${ }^{23}$ Article 12 of the Rio Declaration on Environment and Development, supra note 9, provides that "unilateral actions to deal with environmental challenges outside the jurisdiction of the importing country should be avoided. Environmental measures addressing transboundary or global environmental problems should, as far as possible, be based on an international consensus." There may be serious threats to the global environment that merit immediate attention where international consensus is not yet possible.

${ }^{24}$ Code of Conduct on the Distribution and Use of Pesticides (Nov. 28, 1985), 23 FAO Conf. REs. 10/85, as amended Dec. 1989, FAO Doc. M/U0610E/I/9.90.

${ }^{25}$ UNEP Governing Council Decision, London Guidelines for the Exchange of Information on Chemicals in International Trade (May 25, 1989), UNEP GC/DEC/15/30, UN Doc. UNEP/ PIC.WG.2/4 (1989).

${ }^{26}$ This is consistent with Article 12 of the Rio Declaration, supra note 23. See Raymond Hill, Problems and Policy for Pesticide Exports to Less Developed Countries, 28 NAT. Resources J. 699 (1988). 
to the environmental sustainability of particular ecosystems or living resources within the producing country? While one may argue that, in areas outside any national jurisdiction, under certain conditions trade measures may be needed to forestall serious, perhaps irreversible, degradation from occurring before an international instrument can be negotiated, the argument is more difficult to make for areas within national jurisdiction, since no international instrument may ever be contemplated. Yet increasingly we find that many aspects of the environment within countries do affect the environment elsewhere. Thus, it may be useful in the future to consider reaching agreement on guidelines regarding when unilateral action might be justified. ${ }^{27}$ It is not inconceivable that the follow-up to Agenda 21 of the Earth Summit will lead to the emergence of a consensus on at least minimum environmental norms needed for sustainable development within countries.

Schoenbaum identifies one of the most controversial environment and trade issues: namely, the differences in environmental standards. He proposes that GATT sponsor a new negotiation of an environmental code setting forth minimum environmental standards for certain key economic sectors and that violations of the code then be treated as subsidies subject to a countervailing duty.

From the environmental perspective, countries must be concerned with adopting and enforcing standards that ensure environmentally sustainable development in each country. Differences in environmental standards may often reflect differences in levels of economic development and resources available to protect the environment. Treating such differences as subsidies and invoking countervailing duties are indirect means at best of fostering better environmental conditions and are unlikely to be effective.

From the trade perspective, differences in standards represent an advantage and the advantage gained from lower standards should be eliminated by imposing a countervailing duty in the amount of the subsidy represented by the lower standards. While conceptually clear, this approach is likely to be difficult to apply to environmental standards. Environmental regulatory frameworks differ significantly, so that precise comparisons between even Western European countries and the United States are problematical. The few studies ${ }^{28}$ that have looked at this issue have concluded that, in the European context, differences in standards are hard to compare quantitatively and that many other factors, other than differences in environmental standards, affect the price of the product. This means that it is difficult to identify and quantify the amount of subsidy due to differences in environmental regulation.

Moreover, in many countries, while the environmental legislation may be in place, enforcement is lax. Although some countries have the means to gather enforcement data for purposes of fixing a countervailing duty, it is a difficult, time-consuming, and otherwise expensive task. Enforcement normally takes place

\footnotetext{
${ }^{27}$ See U.S. Office of Technology Assessment, Trade and Environment: Conflicts and OpPORTUNITIES 7 (1992). Already countries have considered controlling exports of such products as pesticides to other countries on the basis of the environmental effects in the country of import.

${ }^{28}$ See, e.g., Raymond Kopp, Paul Portney \& Diane DeWitt, International Comparisons of Environmental Regulation (Resources for the Future discussion paper, 1990) (comparing controls on air and water pollution and hazardous waste in the United States and in OECD countries); U.S. ENVIRONMENtal Protection Agency, International Comparison of Air Pollution Control (1988). Section 811 of the U.S. Clean Air Act Amendments of 1990 requires comparative study of the competitive effects of the significant U.S. air quality control standards and those of the major trading partners. Clean Air Act Amendments of 1990, Pub. L. No. 101-549, 104 Stat. 2399 (1990).
} 
at different levels of government, and communication between them may not be complete or timely. In addition, there will be a concern that the process would be highly intrusive, as the responsible ministry may feel that enforcement priorities would be set not by the environmental needs of the country but by the likelihood that countervailing duty cases would arise against factories manufacturing certain products. In this situation, enforcement of environmental standards affecting public services, such as municipal water supply, or conservation of natural resources, such as parks and living resources, would likely be given lower priority.

One way to view this issue is to ask whether the United States would be willing to have its environmental enforcement record subjected to detailed scrutiny to determine whether its failure to enforce specific standards against certain manufacturers of products in a given sector constituted a subsidy that could be countervailed. Resources for enforcement will always be insufficient, which means that priorities must be set, and it is highly questionable that the setting of these priorities should be driven by trade considerations.

It is perhaps useful to focus on the large area of congruence between national/ international environmental law and international trade law. If we reframe the issue this way, we may be able to move forward more expeditiously. In the debate about sustainable development, it has become clear that environment and economics are inextricably linked. Similarly, environmental protection and trading practices are inextricably linked. Much of what countries have done to protect the environment or to foster freer trade has not raised any legal issues involving their interface. Indeed, from the international and national environmental perspective, most international agreements and even national laws have implications for trade, but they have thus far raised no serious international concern.

Almost all agreements that govern marine mammals, fisheries and other living resources affect trade. Similarly, agreements controlling pollution or governing products and processes that are harmful to the environment affect trade. The main point of controversy in these agreements has been narrow, namely, the consistency with the GATT of provisions that exclude trade with third parties or with countries in noncompliance with the agreement.

Several important agreements-the Montreal Protocol on the Depletion of the Ozone Layer, the Basel Convention on the Control of Transboundary Movements of Hazardous Wastes and Their Disposal, and the Convention on International Trade in Endangered Species-contain provisions that restrict trade in targeted products, wastes or resources with third parties that are not parties to the agreement or are in violation of it. ${ }^{29}$ These provisions are frequently referenced as the only provisions raising trade issues. More accurately, they may be the only ones raising controversial issues of consistency with the GATT, but they are not the only trade-related issues.

As we move forward, it is useful to highlight differences in the two "cultures." The environmental community is generally an open one that is accustomed to demanding public participation in decision making and to relying on public access

\footnotetext{
${ }^{29}$ Montreal Protocol on Substances That Deplete the Ozone Layer, Sept. 16, 1987, S. TREATY Doc. No. 10, 100th Cong., 1st Sess. (1987), reprinted in 26 ILM 1541 (1987); Basel Convention on the Control of Transboundary Movements of Hazardous Wastes and Their Disposal, Mar. 22, 1989, UN Doc. EP/IG.80/3, reprinted in 28 ILM 649 (1989); Convention on International Trade in Endangered Species of Wild Fauna and Flora, Mar. 3, 1973, 27 UST 1087, 993 UNTS 243.
} 
to government information. Environmental nongovernmental organizations consider that they have an essential role in keeping governments accountable for their environmental protection practices. National environmental legislation, such as the Clean Air Act and the Clean Water Act, provides for citizen suits to enforce the statutes against the government. Other statutes require public hearings and, for major federal projects with a significant environmental impact, an environmental impact statement in which the public is given an opportunity to comment.

By contrast, the relationship between the trade community and government is more closed. Government trade specialists are not accustomed to living in a goldfish bowl in making and implementing trade policy. Trade statutes do not provide for citizen suits to force government to comply with its statutory obligations. Nor is the trade community as accustomed to operating in the public eye in its relationship with government. This means that, as the two communities move forward to address environment and trade issues, they will have to develop an effective operational process of interaction that is acceptable to the cultures they represent.

In June 1992, countries and nongovernmental representatives from across the world met at the United Nations Environment and Development Conference in Rio de Janeiro to forge a consensus on the path to environmentally sustainable development in the decades ahead. Environmentally sustainable development offers the appropriate framework in which to view issues of environment and trade, or trade and environment.

EDITH BROWN WEISS*

* Of the Board of Editors. 